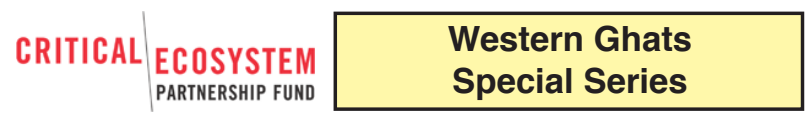

\section{REDISCOVERY OF OPHIORRHIZA BARNESII C.E.C. FISCH. (RUBIACEAE) FROM THE SOUTHERN WESTERN GHATS, KERALA, INDIA}

\author{
E.S. Santhosh Kumar ${ }^{1}$, P.E. Roy ${ }^{2} \&$ S.M. Shareef ${ }^{3}$ \\ 1,2,3 Jawaharlal Nehru Tropical Botanic Garden and Research Institute, Palode, \\ Thiruvananthapuram, Kerala 695562, India \\ ${ }^{1}$ santhoshkumares@gmail.com (corresponding author), ${ }^{2}$ roytbgri@gmail.com, \\ ${ }^{3}$ smshariftbgri@gmail.com
}

The genus Ophiorrhiza L. has about 150 species distributed mainly in the Indo-Malasian region (Mabberley 2008). In India, it is represented by 47 species (Deb \& Mondal 2001) of which 20 are recorded from Kerala (Nayar et al. 2006).

As part of the collection and ex situ conservation of threatened plants of the southern Western Ghats, Ophiorrhiza barnesii C.E.C. Fisch. was rediscovered from the Kallar Valley of the Idukki District in Kerala. The identity of the species was later confirmed by comparing with the type specimen (Barnes 1754) housed at Royal Botanic Gardens, Kew.

O. barnesii was described by C.E.C. Fischer in 1939 based on two collections made by Prof. Edward Barnes (Barnes 1753 \& 1754) from the Kallar Valley of Idukki District in 1937. These are the only known collections of the species since 1937. Deb \& Mondal $(1987,2001)$ considered it as 'possibly extinct'. The present collection of this species is a rediscovery after 75 years of its first collection. It is described and illustrated here.

\section{Ophiorrhiza barnesii C.E.C.} Fisch. (Images 1-2)

Bull. Misc. Inform. Kew 1939:

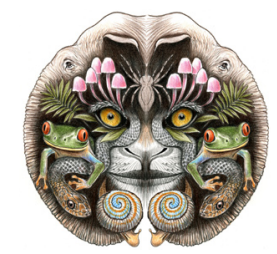

ISSN

Online 0974-7907 Print 0974-7893

\section{OPEN ACCESS} 248.1939.

Perennial erect herbs, woody at base, terete and glabrous below. Leaves ovate-lanceolate to lanceolate, 4.5-11x1.7-3.5 cm, attenuate at base, entire along margins, caudate-acuminate at apex, slightly asymmetric, glabrous or minutely puberulous and dark green above, pale beneath; lateral nerves 6-12 on either side; petioles to $2 \mathrm{~cm}$ long, glabrous; stipules subulate, $1.5-$ $2.5 \mathrm{~mm}$ long, entire, glabrous. Inflorescence in axillary, trichotomous, corymbose cymes, $2.5-3.5 \mathrm{~cm}$ across, glabrous. Peduncle $3-5 \mathrm{~cm}$ long, elongating up to $7 \mathrm{~cm}$ long in fruits, glabrous. Flowers white; pedicels to $3 \mathrm{~mm}$ long; bracts and bracteoles linear, 3-9x1-2 mm long, 1-nerved, acuminate, glabrous. Hypanthium obovoid, glabrous. Calyx lobes ovate-lanceolate, to $2 \mathrm{~mm}$ long, acute at apex, glabrous. Corolla infundibuliform, 9-10 $\mathrm{mm}$ long, glabrous except for a villous ring at the middle of corolla tube; lobes ovate, ca. $3 \times 1.8 \mathrm{~mm}$, acute, glabrous. Stamens adnate to middle of corolla tube; filaments to $2.5 \mathrm{~mm}$ long, glabrous; anthers oblong-linear, ca. $1.5 \mathrm{~mm}$ long. Ovary obovoid, 0.6-0.8x0.4-0.7 mm; style 2-2.5 $\mathrm{mm}$ long, glabrous; stigma 2-lobed, lobes narrowly acute or obtuse, entire, warty. Capsules 2-3.5x4.5-8.5 mm, glabrous, locules ovate-oblong. Seeds many in each locule, 5-8 angular, glabrous, brown.

DOI: http://dx.doi.org/10.11609/JoTT.o3241.4115-7

Editor: P. Lakshminarasimhan, Botanical Survey of India, Howrah, India.

Date of publication: 26 April 2013 (online \& print)

Manuscript details: Ms \# 03241 | Received 27 June 2012 | Final received 11 February 2013 | Finally accepted 21 March 2013

Citation: Kumar, E.S.S., P.E. Roy \& S.M. Shareef (2013). Rediscovery of Ophiorrhiza barnesii C.E.C. Fisch. (Rubiaceae) from the southern Western Ghats, Kerala, India. Journal of Threatened Taxa 5(7): 4115-4117; http://dx.doi.org/10.11609/JoTT.03241.4115-7

Copyright: (C) Kumar et al. 2013. Creative Commons Attribution 3.0 Unported License. JoTT allows unrestricted use of this article in any medium, reproduction and distribution by providing adequate credit to the authors and the source of publication.

Funding: Jawaharlal Nehru Tropical Botanic Garden and Research Institute, Thiruvananthapuram, Kerala, India

Competing Interest: None.

Acknowledgements: The authors are grateful to the Director, JNTBGRI, Thiruvananthapuram for the facilities provided and to Dr. P.J. Mathew, Head, Division of Plant Genetic Resources, JNTBGRI for the encouragements.

The publication of this article is supported by the Critical Ecosystem Partnership Fund (CEPF), a joint initiative of l'Agence Française de Développement, Conservation International, the European Commission, the Global Environment Facility, the Government of Japan, the MacArthur Foundation and the World Bank. 

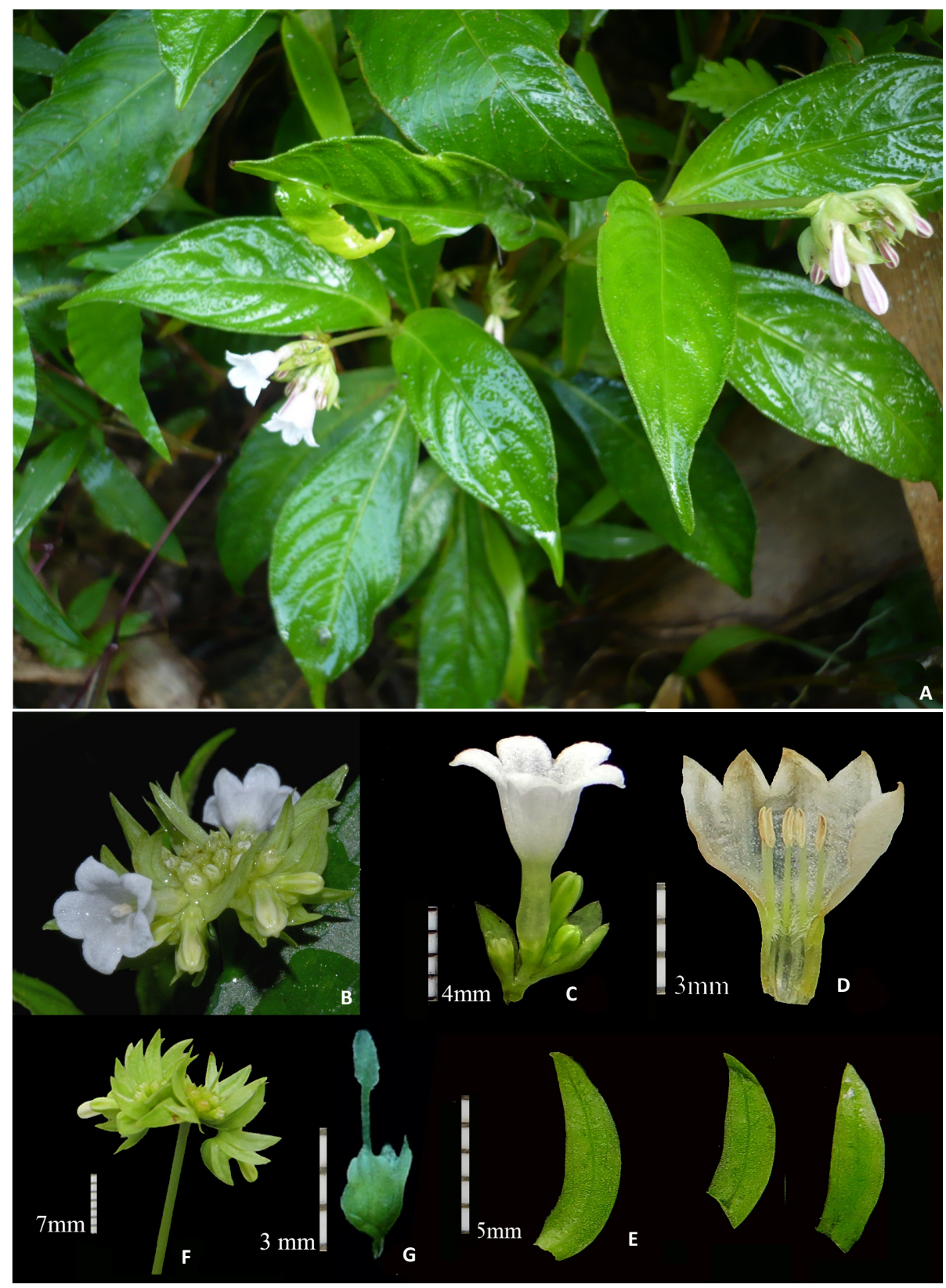

Image 1. Ophiorrhiza barnesii C.E.C. Fisch.

A - Habit; B\&F - Inflorescence; C - Flower and flower buds; D - Corolla spread out showing anthers; E - Bracts; G - Gynoecium. Photo credit: Dr. E.S. Santhosh Kumar

Specimens examined: 70440 (Tropical Botanic Garden, Thiruvananthapuram (TBGT)), 21.ii.2012, 1400m, Kallar Valley, Idukki District, Kerala, India, E.S. Santhosh Kumar \& P.E. Roy.

Flowering and fruiting: September-December.

Habitat and Ecology: This species is found growing in the under storey of the evergreen forests at an altitude of 1200-1600 m and are usually seen along the banks of streams or rivulets usually associated with Sonerila wallichii, Ophiorrhiza roxburghiana, O. barberi,

\section{Elatostemma sp., etc.}

Note: Ophiorrhiza falcata, was described by Beddome in 1861, from the moist woods of Anamalais, at altitudes of 914-1219 m. This species has not been collected by any subsequent workers from these regions. Beddome's description is the only clue which states: "Erect, everywhere glabrous, leaves lanceolate, tapering at both ends, acuminate, very pale beneath; stipules large subulate to triangular, cymes axillary and terminal long peduncled with 3-reflexed secondary division, 2 of 


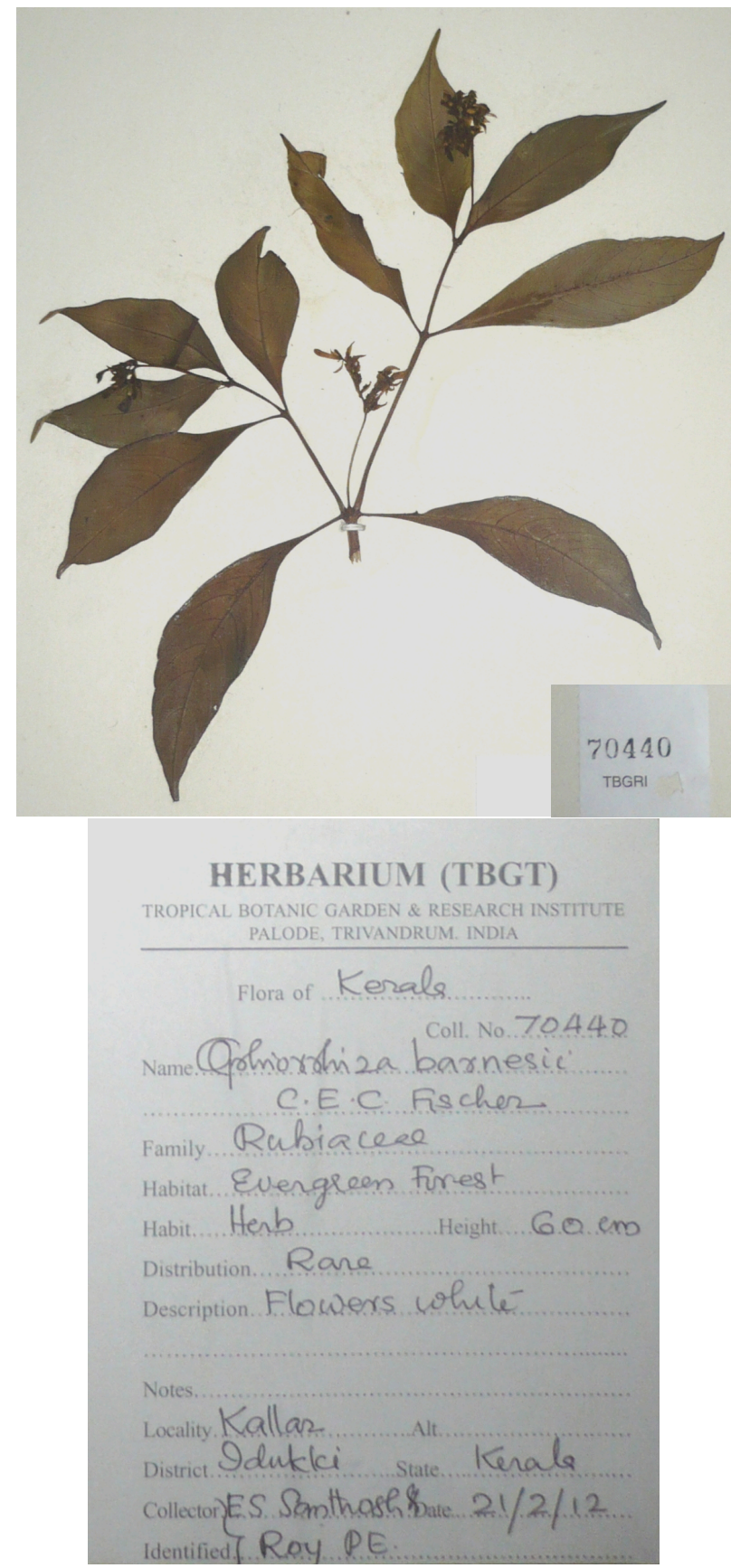

Image 2. Herbarium specimen image of Ophiorrhiza barnesii C.E.C. Fisch. which are generally 2-partite; bracts large falcate, calyx minute, flower bud angled; corolla gibbous at base and contracted below the segments, glabrous outside, hairy in the jaws above the anthers, etc". This description appears to be similar to $O$. barnesii. This prompted us for a detailed study of both species. Unfortunately, there is no mention of any specimen in the protologue and searching the specimens at The British Museum, Natural History (BM); Royal Botanic Gardens, Kew (K) and The Nationaal Herbarium, The Netherlands ( $L$ ) also became futile. It is possible that Beddome never kept a specimen of his species; hence a comparison of $O$. barnesii and $O$. falcata is quite impossible. More field surveys in the Anamalai Hill ranges definitely would tell us the real status of $O$. falcata, hence we are refraining from merging them together for the time being.

We have introduced a few individuals to the Field Gene Bank of JNTBGRI for its ex situ conservation and future studies.

\section{REFERENCES}

Deb, D.B. \& D.C. Mondal (1987). Ophiorrhiza barnesii Fischer, P. 90. In: Nayar, M.P \& A.R.K. Sastry (ed.). Red Data Book of Indian Plants. Vol. 1. Botanical Survey of India, Kolkata.

Deb, D.B. \& D.C. Mondal (2001). Taxonomic Revision of the genus Ophiorrhiza L. (Rubiaceae) in Indian subcontinent. Bulletin Botanical Survey of India 39: 1-148.

Fischer, C.E.C. (1939). New or Little known plants from southern India: X. Bulletin of the Miscellaneous Information Kew 1939: 248.

Mabberley, D.J. (2008). Mabberley's Plant-Book: A Portable Dictionary of Plants, Their Classification and Uses Utilizing Kubitzki's The Families and Genera of Vascular Plants (1990-onwards) and Current Botanical Literature; Arranged According to The Principles of Molecular Systematics (Third Edition). Cambridge University Press, Cambridge, UK, 603pp.

Nayar, T.S., B. Rasiya, N. Mohanan \& G.R. Kumar (2006). Flowering Plants of Kerala - A Handbook. Tropical Botanic Garden and Research Institute, Thiruvananthapuram, 125pp. 